\title{
Áfram á rauðu ljósi - fjármálahrunið á Íslandi og reynsla Norðurlandanna
}

\author{
Már Wolfgang Mixa og Pröstur Olaf Sigurjónsson ${ }^{1}$
}

\begin{abstract}
Ágrip
Á síðustu árum hafa fræðimenn borið saman fjármálakreppur til að skilja betur pær aðstæður sem myndast í undanfara kreppu. Pessari grein er ætlað að varpa ljósi á pað hvort Íslendingar flutu sofandi að feigðarósi í aðdraganda fjármálakreppunnar árið 2008. Viðfangsefnið beinist að pví hvort Íslendingar hefðu átt að sjá viðvörunarmerkin með pví að líta til reynslu annarra landa sem nýlega höfðu glímt við fjármálakreppu. Rannsókn pessi ber undanfara íslensku fjármálakreppunnar saman við undanfara norrænu kreppunnar í upphafi tíunda áratugarins. Niðurstaðan er sú að einkennin voru afar lík og pað gaf tilefni til að ætla að djúp kreppa væri í aðsigi á Íslandi. Sígild merki um undanfara kreppu sáust jafnvel enn skýrar á Íslandi.
\end{abstract}

\begin{abstract} crisis were even more evident in Iceland.

JEL flokkun: G010

Lykilhugtök:Hrun, kreppur, fjármál, fjármálakreppur, regluverk.
\end{abstract}

Academics have in recent years compared financial crises in order to gain a better understanding of preceding circumstances. This paper explores whether Icelanders were oblivious to historical warning signals preceding the financial crisis in 2008. A specific focus is on whether Icelanders should have seen warning signals by exploring warning signs in other countries that have recently dealt with financial crises. This research compares the prelude of Iceland's financial crisis to preceding circumstances of the Scandinavian crisis during the early 1990s. The result is that the characteristics showed remarkable similarities indicating that a deep crisis was brewing in Iceland. Classic symptoms of a prelude to a

\footnotetext{
${ }^{1}$ Pröstur Olaf Sigurjónsson er lektor við viðskiptadeild Háskólans í Reykjavík og Már Wolfgang Mixa er doktorsnemi við viðskiptadeild Háskólans í Reykjavík. 


\section{Inngangur}

Sjaldan, ef nokkurn tíma, hefur vestrænt ríki purft að glíma við fjármálakreppu af sömu stærðargráðu og íslenska pjóðin nú. Afleiðingarnar eru meðal annars aukin skuldsetning ríkissjóðs, úr 23\% af vergri landsframleiðslu (VLF) í árslok 2007 (Fjármálaráðuneytið, 2009) í 78\% í árslok 2009 (Fjármálaráðuneytið, 2010). ${ }^{2}$ Raunlækkun á virði fasteigna á höfuðborgarsvæðinu nemur um priðjungi í lok árs 2009 samanborið við húsnæðisvísitöluna í ársbyrjun 2008 pegar nafnvirði hennar náði hámarki (Fasteignaskrá ríkisins, 2009; Hagstofa Íslands, 2009). Til að skilja ástæður pessara ófara er gagnlegt að bera aðdraganda íslensku fjármálakreppunnar saman við fjármálakreppur annarra landa. Samanburður við aðrar Norðurlandapjóðir er nærtækur en pær fóru í gegnum fjármálakreppu í upphafi tíunda áratugarins. Samfélög norrænu pjóðanna og Íslands eru um margt lík og pað gerir slíkan samanburð áhugaverðan. Hinar norrænu pjóðirnar purftu flestar að leggja talsvert fé til banka sinna. Hægt er að tala um að kerfislegt áfall hafi átt sér stað. Aðstæðum í Svípjóð og Finnlandi svipaði að mörgu leyti saman, jafnvel að pví marki að talað hefur verið um tvíburakreppur. Fjármálakerfið í Danmörku purfti hins vegar lítinn stuðning og glímdi ekki við kerfislegt áfall (Honkapohja, 2009). •ó að almennt sé talað um norrænu bankakreppuna voru pað fyrst og fremst Svípjóð og Finnland sem glímdu við hana (Jonung, Kiander \& Vartia, 2008). Bankakreppa reið yfir Noreg en aðeins fyrr og loks má geta pess að alvarleg bankakreppa skall einnig á í Færeyjum í upphafi tíunda áratugarins. Í pessari grein er sjónum aðallega beint að Svípjóð og Finnlandi en einnig Noregi.

Samanburðargreining á íslenska hruninu árið 2008 og erlendum fjármálakreppum hefur ekki verið birt svo að höfundum sé kunnugt. Hins vegar hefur talsvert verið skrifað um norrænu fjármálakreppurnar og pær bornar saman hver við aðra (Honkapohja, 2009; Jonung, Kiander \& Vartia, 2008; Berg, 1998; Englund \& Vihriala, 2003; Jonung, 2008; Jonung, 2009). Pessi skrif hafa aukið skilning á peim aðstæðum sem urðu kveikjan að norrænu fjármálakreppunum. Rannsóknarspurning pessarar greinar er hvort óveðrið, sem skall á íslensku fjármálalífi, hafi verið án viðvörunarmerkja og hvort ekki hefði verið hægt að læra af reynslu norrænu pjóðanna. Sérstök áhersla er lögð á pann pátt í íslensku viðskiptalífi sem nær til losunar regluverks á níunda og tíunda áratugnum og einkavæðingar bankanna.

Aukinn skilningur á orsökum íslenska fjármálahrunsins fæst með pví að bera próun og formgerð norrænu fjármálakreppunnar saman við íslensku aðstæðurnar (Sigurjónsson, 2010a). Slíkur samanburður er gerður með áherslu á samnefnara peirra og hvaða atriði skilja pær að. Petta veitir vísbendingu um alvarleika íslensku kreppunnar.

Uppbygging greinarinnar er eftirfarandi. Fyrst er undanfara mikils efnahagsvaxtar á Íslandi lýst og áhersla lögð á pær breytingar sem áttu sér stað í efnahags- og

2 Í viðtali Ríkissjónvarpsins 15. nóvember 2009 við Mats Josefsson, einn helsta ráðgjafa ríkisins við endurreisn íslenska bankakerfisins, kemur fram sú skoðun hans að núverandi bankakreppa á Íslandi sé sú stærsta sem heimurinn hafi séð. Hann telur skuldaaukningu ríkisins að mestu leyti til komna vegna kostnaðar við endurreisn bankakerfisins. Í viðtalinu gerir Josefsson ráð fyrir kostnaði sem samsvari $85 \%$ af VLF en pað er nálægt páverandi spá um aukningu á skuldum ríkisins í lok ársins 2009 (Fjármálaráðuneytið, 2009). Samkvæmt nýjustu tölum er sú tala lægri eða um 55\%. Til samanburðar var kostnaðurinn, samkvæmt Josefsson, 51\% í Indónesíu, 25\% í Tælandi og 23\% í Tyrklandi. Englund og Vihriala (2003) áætla að kostnaðurinn hafi verið um 5\% af VLF í Svípjóð (Josefsson bendir á að sá kostnaður hafi fengist til baka og jafnvel gott betur) og 14\% í Finnlandi. 
Tafla 1. Próun umgjarðar fjármálakerfisins á Íslandi

\begin{tabular}{ll}
\hline Viðburður & Ár \\
\hline Verðtrygging leyfð & 1979 \\
\hline Bankavextir gefnir frjálsir & $1984-1986$ \\
\hline Kauphöll Íslands stofnuð & 1985 \\
\hline Vextir að fullu gefnir frjálsir & 1987 \\
\hline Afnám hafta á fjármagnshreyfingum hefst & 1990 \\
\hline Lokun á yfirdráttarheimild ríkis í Seðlabankanum & $1992-1993$ \\
\hline Nýjar reglur um gjaldeyrisviðskipti / einkavæðing hefst & 1992 \\
\hline Millibankamarkaður með erlendan gjaldeyri settur á stofn & 1993 \\
\hline Ísland verður stofnmeðlimur EES-samnings & 1994 \\
\hline Langtíma fjármagnshreyfingar gefnar frjálsar & 1994 \\
\hline Skammtíma fjármagnshreyfingar gefnar frjálsar & 1995 \\
\hline Erlendar fjárfestingar heimilaðar í samræmi við EES-samninginn & 1995 \\
\hline Millibankamarkaður stofnaður / einkavæðing banka hafin & 1998 \\
\hline Millibankamarkaður með erlendan gjaldeyri stofnaður & 2001 \\
\hline Einkavæðingu ríkisbankanna lokið & 2003 \\
\hline
\end{tabular}

Heimild: Seðlabanki Íslands (2006a) og höfundar.

viðskiptaumhverfi landsins í kjölfar losunar hafta. Kaflinn veitir yfirsýn yfir pætti sem að mörgu leyti stuðluðu að hruni fjármálakerfisins. Pá er árangur af einkavæðingu íslensku bankanna greindur með áherslu á vöxt peirra og aukna áhættusækni. Í framhaldinu er falli íslensku bankanna lýst. Gerð er grein fyrir norrænu fjármálakreppunni á tíunda áratugnum og samhliða gerður samanburður á henni og íslensku kreppunni. Megindlegur samanburður er gerður á bönkunum en jafnframt eru aðstæður í ríkisfjármálum og peningastefnu skoðaðar. Að lokum er fjallað um hvort og pá hvaða lærdóm Ísland getur dregið af reynslu norrænu pjóðanna.

\section{Viðskiptaleg og efnahagsleg endurskipulagning á Íslandi}

Fyrir tuttugu árum var hafist handa við losun hafta sem dregið höfðu aftur af íslensku viðskipta- og efnahagslífi. Pessi próun átti sér stað á löngu tímabili eins og tafla 1 sýnir.

Landsbanki og Búnaðarbanki voru síðastir í röð einkavæddra ríkisfyrirtækja en einkavæðingu peirra lauk árið 2003. Samhliða einkavæðingunni og í kjölfar hennar hófst hrina sameininga og uppkaupa banka, í fyrstu aðallega innanlands en síðan erlendis. Á mynd 1 er yfirlit yfir próun varðandi sameiningar og kaup íslenskra banka um og eftir einkavæðingu.

Einkavæðingin skóp umhverfi par sem bankarnir gátu vaxið frekar og hjá öllum bönkunum var litið til tækifæra erlendis. Í upphafi fyrsta áratugar nýrrar aldar voru vextir á heimsvísu í sögulegu lágmarki en pað, ásamt lægra áhættuálagi, hvatti til vaxtar. Á sama 


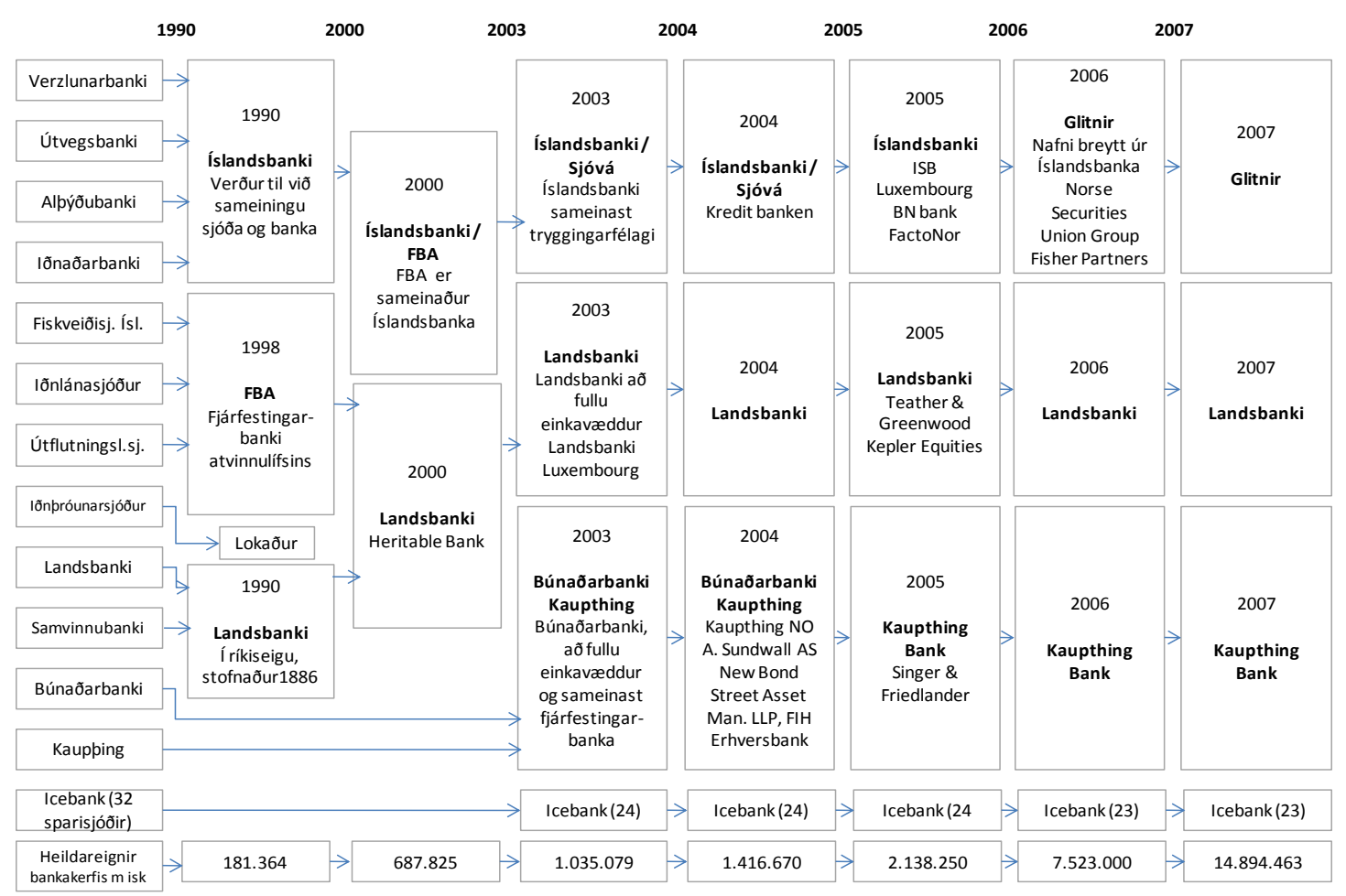

Mynd 1. Yfirlit yfir próun íslenskra banka

Heimild: Seðlabanki Íslands (2007) og höfundar.

tíma var eignavöxtur sterkur á Íslandi og á alpjóðamörkuðum, sérstaklega hvað varðar verð fasteigna og hlutabréfa. Íslensku bankarnir nutu góðs af örum vexti ýmissa atvinnugreina á Íslandi, svo sem lyfjageirans, fyrirtækja í matvælaframleiðslu, verslunarrekstrar og samgangna. Hvati fyrirtækjanna til að vaxa var sá sami og hjá bönkunum, aðlaðandi ytri aðstæður á alpjóðlegum vettvangi. Að sama skapi nutu „nýju“ einkavæddu bankarnir góðs af pví lánshæfismati sem ríkisbankarnir nutu áður. Peir hófu markvissa leit að viðskiptavinum sem gætu stutt við vöxt peirra erlendis. Bankarnir voru hins vegar ekki einvörðungu lánveitendur. Peir voru frekar ráðgjafar og tóku stöðu með hlutabréfakaupum viðskiptavina sinna. Pannig urðu peir oft nátengdir viðskiptavinum sínum (Portes og Baldursson, 2007). Pessi tenging leiddi smám saman til pess að bankarnir urðu háðir fáeinum stórum viðskiptavinum sem fæstir höfðu landfræðilega eða rekstrarlega áhættudreifingu. Með nýja skipulaginu jukust líkur á hagsmunaárekstrum.

Íslensku bankarnir störfuðu ekki lengi án erlendrar gagnrýni. Раð sem hefur verið kallað Informational Crisis skall á bönkunum í byrjun árs 2006 (Portes \& Baldursson, 2007). Hörðust var gagnrýnin frá Fitch Ratings og Danske Bank (Seðlabanki Íslands, 2006b; Valgreen, 2006). Gagnrýnin snerist að mestu um skort á gagnsæi og upplýsingum um viðskiptalíkön og rekstur íslensku bankanna. Einnig var gagnrýnt hversu háðir bankarnir voru fjármögnun á markaði (e. wholesale market) og hversu hátt hlutfall skammtímalána var (bankarnir fengu skammtímalán en lánuðu sjálfir langtímalán) (Merrill Lynch, 2006). Pessar aðstæður gerðu bankana viðkvæma fyrir mögulegum óróa á fjármálamörkuðum og lausafjárkreppu. Greiningaraðilar Merrill Lynch (2006) lýstu einnig yfir efasemdum um gæði eigna bankanna, krosseignarhald og almennan skort á gagnsæi í rekstri peirra. Skýrslu Portes og Baldurssonar (2007) var ætlað að varpa ljósi á ofangreinda gagnrýni.

Í framhaldi af neikvæðri umræðu, auk óróleika á erlendum mörkuðum, lækkaði gengisvísitala íslensku krónunnar um $25 \%$ og innlenda hlutabréfavísitalan féll um svipað 
Tafla 2. Vöxtur eigna íslenskra banka í samanburði við norræna banka

\begin{tabular}{lccccccc}
\hline $\begin{array}{l}\text { Vöxtur } \\
\text { eigna }\end{array}$ & Glitnir & Kaupping & $\begin{array}{l}\text { Lands- } \\
\text { banki }\end{array}$ & $\begin{array}{l}\text { Svenska } \\
\text { Handelsb. }\end{array}$ & $\begin{array}{l}\text { Danske } \\
\text { Bank }\end{array}$ & $\begin{array}{l}\text { Nordea } \\
\text { Ben Norske } \\
\text { Bank }\end{array}$ \\
\hline $2001-2007$ & 8,5 & 12,4 & 11,4 & 1,6 & 2,2 & 1,6 & 2,5 \\
\hline \multicolumn{7}{c}{ Heimild: Ársskýrslur bankanna og útreikningar höfunda. }
\end{tabular}

hlutfall. Раð var almenn skoðun að pessi lækkun tengdist neikvæðu viðhorfi erlendra aðila til stöðu bankanna (Portes \& Baldursson, 2007). Eftir einkavæðingu höfðu íslensku bankarnir fjármagnað hraðan vöxt sinn á heildsölumarkaði með lánum frá öðrum fjármálastofnunum en ekki með innstæðum viðskiptavina sinna. Að sama skapi var sett spurningarmerki við hátt hlutfall óreglulegra tekna í rekstrarreikningum peirra en pað hlutfall fór upp undir $50 \%$ (ársreikningar íslensku bankanna, 2003-2006). Bankarnir voru pegar hér var komið sögu nauðbeygðir til að breyta um stefnu. Heildsölufjármögnun var peim lokuð og peir urðu að leita á önnur mið til að auka innlán sín.

Frá árinu 2003 jókst stöðugt vaxtamunur á milli íslensku krónunnar og erlendra mynta, bæði vegna hækkandi stýrivaxta á Íslandi og vegna pess að stýrivextir á alpjóðamörkuðum voru í sögulegri lægð. Íslensku bankarnir nýttu sér pessar aðstæður og tóku mikið af lánum erlendis. Á skömmum tíma pandist efnahagsreikningur peirra út og í árslok 2007 nam hann orðið um pað bil ellefu- til tólffaldri vergri landsframleiðslu (Hagstofa Íslands, 2009; Seðlabanki Íslands, 2010), par af voru um 2/3 í erlendri mynt (Már Guðmundsson, 2010). Með gríðarlega auknu innflæði fjármagns jukust áhyggjur af flóknu krosseignarhaldi og ógagnsæi í starfsemi bankanna enn frekar.

\section{3 Áhrif einkavæðingar á rekstur bankanna}

Pegar litið er til íslenska bankakerfisins í sögulegu samhengi er rétt að horfa til pess að á árunum 1984-2001 var losað um höft í íslensku atvinnulífi í umtalsverðum mæli samhliða einkavæðingu ríkisfyrirtækja. Gætt var að samkeppnissjónarmiðum, til að mynda með pví að leyfa ekki samruna einkavæddra ríkisbanka við einkabanka. Ríkisvaldið styrkti hlutabréfamarkað með skattaívilnun vegna hlutabréfakaupa ásamt pví að lækka umtalsvert skatt á fyrirtæki, einstaklinga og fjármagn (Sigurjónsson, 2010b). Farnar voru algjörlega nýjar leiðir við hvatakerfi starfsfólks bankanna og voru pær í takti við pað sem pekktist hjá alpjóðlegum fjárfestingarbönkum.

Einkavæddu bankarnir, ásamt Glitni (sem hafði orðið til við samruna Fjárfestingarbanka atvinnulífsins og Íslandsbanka árið 2000), tóku allir pátt í alpjóðavæðingu sem skilaði peim átt- til tólfföldum vexti eigna innan fárra ára. Petta er margfaldur vöxtur á við aðra norræna banka á sama tímabili eins og tafla 2 sýnir.

Íslensku bankarnir reiddu sig á fjármögnun á heildsölumarkaði frekar en innlán. •að hafði ákveðna áhættu í för með sér sem var gagnrýnd af erlendum greinendum (Merrill Lynch, 2006 \& Danske Bank, 2006) og brugðust íslensku bankarnir við pessari gagnrýni. Fljótlega gat Landsbankinn sýnt fram á umtalsverðan viðsnúning og hækkaði mikið hlutfall innlána af heildareignum en bankinn naut mikillar velgengni með Icesave-innlánsreikninga sína í Bretlandi og Hollandi. Hinir tveir íslensku bankarnir náðu pessum hlutföllum sambærilegum við Danske Bank og Svenska Handelsbanken (Sigurjónsson, 2010b).

Aukin skuldsetning pýddi pó aukna viðkvæmni fyrir mögulegum verðlækkunum eigna. Á pví tímabili pegar verð á eignum hækkaði skart (2003-2007), í umhverfi par sem aðgengi 
að lausafé var auðvelt, jókst mikilvægi pess að fjármagnsmarkaðir lentu ekki í lausafjárpurrð (Gylfason, 2009). Hvorki Seðlabanki Íslands né ríkissjóður höfðu svigrúm til pess að koma íslensku bönkunum premur til aðstoðar ef með pyrfti, til pess var ekki til nægur erlendur gjaldeyrir. Fljótlega eftir einkavæðingu var bankakerfið án lánveitanda til prautarvara (Buiter, 2009).

\section{Hrunið}

Á uppgangstímum hvatti öflugur hagvöxtur stjórnendur íslenskra fyrirtækja til dáða og almenningur fylgdist með fullur aðdáunar. Stemningin í samfélaginu virtist skipta meira máli en hátt vaxtastig hvað áhættusækni varðar og kemur pað heim og saman við rannsóknir (Gailbraith, 1997). Traust á sterka leiðtoga og jákvæð almenn fjölmiðlaumræða skiptir miklu máli í pessu samhengi. Með greiðum aðgangi að fjármagni virtust viðskiptatækifærin vera víða. Nægt framboð fjármagns leiddi til hækkunar eignaverðs. Aðgangur að ódýru fjármagni varð lykilpáttur í hækkandi eignaverði. Pegar eignir voru svo skráðar á markaðsvirði hækkaði eigið fé enn meira og aðstæður fyrir nýjar lántökur sköpuðust. Eignaverðbólga hafði orðið til. Pessar aðstæður giltu um flest vestræn ríki par sem vextir voru lágir svo árum skipti og var pað ekki fyrr en á árinu 2007 að neikvæð áhrif fóru að koma fram (Kirkpatrick, 2009).

Íslensku bankarnir urðu fljótt lýsandi dæmi um pá erfiðleika sem hrönnuðust upp í fjármálaheiminum sumarið 2007. Áhættuálag á skuldabréfum peirra rauk upp strax haustið 2007 eftir að Northern Rock í Bretlandi varð gjaldprota. Litlu skiptu yfirlýsingar um að lánasöfn peirra væru að mestu án undirmálslána (e. sub-prime loans). Í lausafjárkreppunni árin 2007-2008 urðu eignir bankanna enn viðkvæmari. Pegar lánveitendur treysta pví ekki lengur að aðrir lánveitendur framlengi lán sín og veiti ný lán tapa bankar trausti sínu og verða fljótt gjaldprota vegna lausafjárpurrðar. Petta átti sérstaklega við um íslenska banka vegna spurninga erlendra greiningaraðila um stöðu peirra.

Með falli fjárfestingarbankans Lehman Brothers varð neikvæðri próun ekki snúið við. Millibankamarkaðir og peningamarkaðir (e. money markets) frusu, sérstaklega til aðila sem póttu veikir fyrir. Fljótlega varð ljóst að ekki aðeins einn íslenskur banki gæti orðið undir heldur allt bankakerfið. Áhlaup var hafið á fjármálakerfi heillar pjóðar, lánalínur frusu og Glitnir varð fyrsti bankinn til að leita til Seðlabankans um líflínu. Ljóst pótti að Glitni yrði ekki bjargað og var bankinn tekinn yfir 6. október 2008. Pegar skammtímafjármögnun hafði horfið kom veðkall frá Seðlabanka Evrópu. Landsbankinn gat með sama hætti ekki staðið við sínar skuldbindingar og var tekinn yfir daginn eftir. Kaupping virtist vera eini bankinn sem enn gat starfað en 6. október fékk bankinn 80 milljarða ISK lán frá Seðlabanka Íslands gegn veði í danska FIH bankanum. Viðbrögð breskra stjórnvalda urðu afdrifarík. Landsbankinn hafði safnað 1.200 milljörðum ISK inn á Icesave-innlánsreikninga í bresku útibúi sínu. Bresk stjórnvöld voru uggandi yfir pessari stöðu svo og lausafjárstöðu dótturfyrirtækis Kauppings, Singer \& Friedlander. Pau settu hryðjuverkalög á íslenskar eignir í Bretlandi og við pað féll Singer \& Friedlander. Í kjölfarið tók íslenska ríkið Kaupping yfir, 9. október 2008 (Jännäri, 2009).

Í ágúst 2008 höfðu allir íslensku bankarnir staðist álagspróf af hálfu Fjármálaeftirlitsins (FME, 2008). Til allrar óhamingju taka slík próf ekki fyrir áhrif lausafjárkreppu. Auk pess gerði prófið ekki ráð fyrir peim sveiflum í gengi gjaldmiðils sem íslenska krónan varð fyrir árið 2008; flöktið var takmarkað við $20 \%$ en veiking krónunnar reyndist vera meiri en $50 \%$ áður en gjaldeyrishöft voru sett á (Kamallakharan \& Tómasson, 2009). Ríkisvaldið hafði rekið 
stefnu afskiptaleysis og FME fékk fá tækifæri til að eflast samtímis miklum vexti bankanna. Á sama tíma og bankarnir stækkuðu meira en tífalt fjölgaði starfsfólki FME úr 27 í 45 (FME, 2009). Hæft starfsfólk FME var auk pess eftirsótt af bönkunum og kusu margir að færa sig yfir í fjármálageirann og njóta betri kjara. Vogarafl bankanna yfir FME jókst stöðugt. Engar hömlur voru á vexti bankanna og djörfu hvatakerfi peirra sem studdi mjög áhættusækni.

\section{Samanburður á kreppum}

Í rannsókn Reinhart og Rogoff (2008) eru átján fjármálakreppur skilgreindar frá eftirstríðsárunum til ársins 2007 pegar undirmálslánakreppan skall á. Höfundar rannsóknarinnar flokka kreppurnar í Noregi, Svípjóð og Finnlandi í byrjun níunda áratugarins meðal peirra fimm stærstu. Niðurstaða peirra er sú að alls staðar megi greina sambærileg atriði sem fara á undan kreppunum. Áhrifaríkar breytingar á regluverki skapa aðstæður sem geta leitt til mikillar útlánaaukningar í fjármálakerfi og pað ýtir undir eignaverðbólgu. Pegar bólgan hjaðnar lækkar eignaverð mjög skart, sérstaklega virði fasteigna, og afleiðingin getur verið fjöldagjaldprot. Tapaðar kröfur og eignarýrnun valda bankakreppu sem, ásamt hruni á gjaldmiðli, eykur tapið enn frekar. Afleiðingin er að lánveitingar til fyrirtækja í rekstri dragast mikið saman og pað eykur enn líkur á kerfishruni og nauðsynlegu inngripi ríkisvalds til hjálpar fjármálakerfinu (Englund, 1999).

Hér er sjónum aðallega beint að Svípjóð og Finnlandi par sem áfallið í Noregi varð nokkru minna og átti sér stað nokkrum árum fyrr. Sérstök ytri áhrif höfðu jákvæða pýðingu fyrir Noreg en olíuverð fór hækkandi á pessum tíma vegna óróleika í Persaflóanum. Afnám hafta átti sér stað tveimur árum fyrr í Noregi en í Svípjóð og Finnlandi. Upphaf norrænu kreppunnar er venjulega rakið til níunda áratugarins pegar hafist var handa við losun regluverks. Рó að ferli breytinga hafi ekki verið alveg eins voru upphaf og lok sambærileg (Englund, Vihriala, 2003). Samnefnari var frelsi til vaxtaákvarðana og öflun fjármagns á alpjóðlegum mörkuðum (Jonung, Kiander \& Vartia, 2008).

Regluverkið í Svípjóð var lítið uppfært í kjölfar breytinga á starfsemi fjármálafyrirtækja (Honkapohja, 2009). Að auki urðu breytingar á skattkerfinu og hvatti pað til aukinnar skuldsetningar, bæði í fyrirtækjarekstri og fyrir heimili (Honkapohja, 2009). Á hinum Norðurlöndunum leið minna en áratugur frá pví að tímabil losunar regluverks hófst pangað til pví var lokið. Áhrif breytinganna komu að fullu fram á premur til fjórum árum en pau mátti merkja á pann hátt að útlán jukust mikið. Tafla 1 sýnir að á Íslandi var petta tímabil miklu lengra, eða tæplega 25 ár, og gerir pað samanburð að einhverju leyti erfiðari.

Pví má segja að árin 1982-1986 væru fyrir hin Norðurlöndin pað sem árin 1984-2003 voru fyrir Ísland. Vaxtartímabili áranna 1986 til 1990 á Norðurlöndunum náðist ekki á Íslandi fyrr en á seinni hluta tíunda áratugarins. Рað pýðir að útlánavöxtur var pá pegar mikill en óhóflegur vöxtur útlána á Íslandi hófst fyrst fyrir alvöru eftir 2003 (sjá mynd 3).

Upphafspunktur fyrir samanburð tímabila er hlutlægur en sameiginlegur grunnur veitir fyrst og fremst innsýn í próun sem átti sér stað á uppgangsárunum. Pví er hér miðað við tímabilið pegar afnám hafta hefst. Með slíkan samanburð í huga er árið 1982 notað sem upphafsár fyrir hin Norðurlöndin, eða um pað leyti sem losun hafta var farin að hafa áhrif, en fyrir Ísland er pað árið 1999 (pegar áhrif af auknu afnámi hafta voru farin að koma í ljós en enn voru engin teikn uppi um óvanalega miklar lánveitingar). Árið 1999 er pví skilgreint sem upphafstímabil, eða T, fyrir Ísland og árið 1982 sem T fyrir Norðurlöndin. 


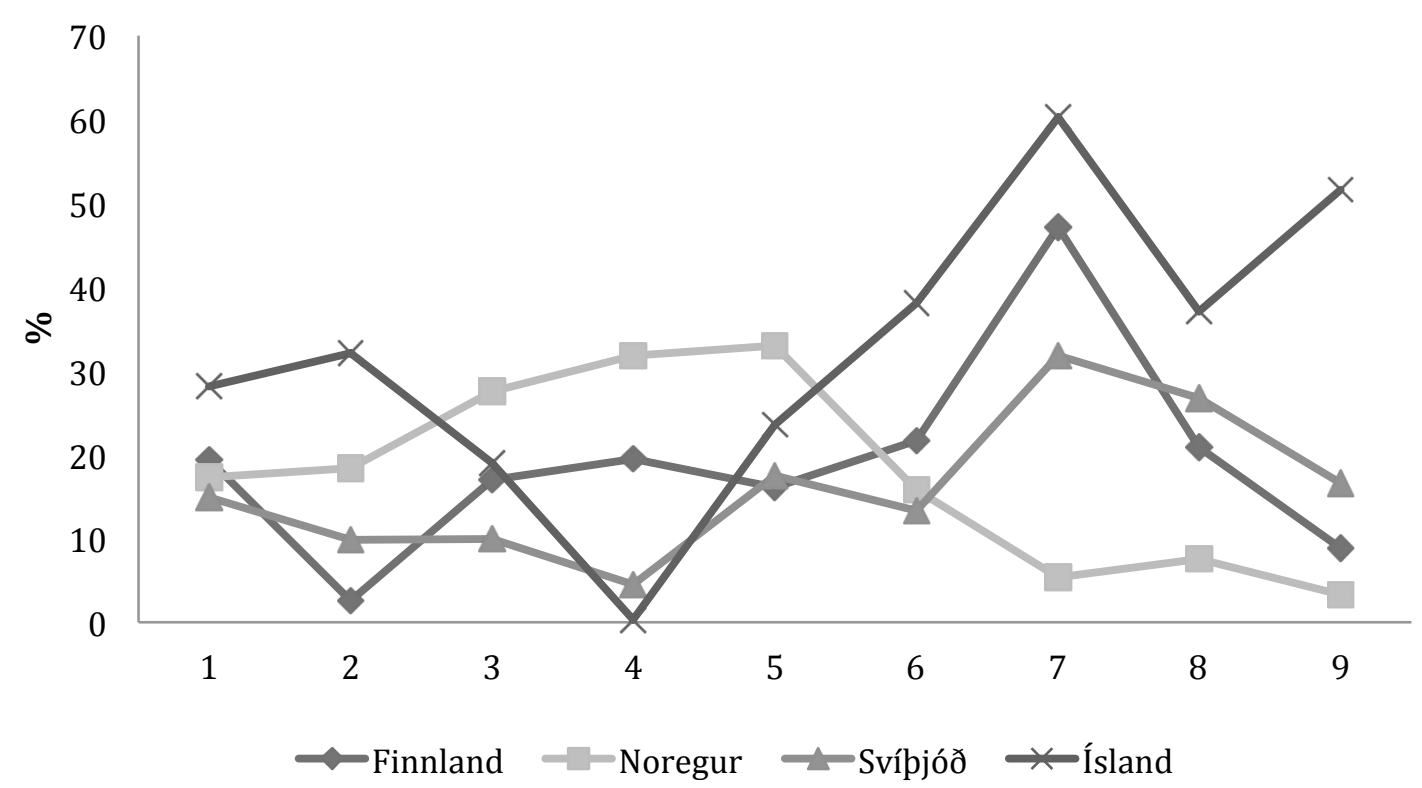

Mynd 2. Samanburður á útlánavexti - Ísland borið saman við hin Norðurlöndin ${ }^{3}$ Heimildir: Honkapohja (2009) og Seðlabanki Íslands (2010)

\subsection{Vöxtur útlána}

Rætur kreppunnar á hinum Norðurlöndunum er að finna við upphaf níunda áratugarins en áhrifin komu af alvöru fram undir lok pess áratugar samfara miklum vexti útlána. Fjármálastofnanir hurfu frá pví að keppa á sviði pjónustu og fóru pess í stað að keppa í verði til að ná sem stærstri markaðshlutdeild (Berg, 1998). Með aukinni samkeppni á vaxtamarkaði hagnaður af hverju láni og var reynt að vega upp á móti slíkri próun með aukningu lána. Eins og sést á mynd 2 leiddi pað af sér stóraukinni áhættusækni í ákvörðunartöku útlána til viðskiptavina (Honkapohja, 2009). Lánveitingar til nýrra markaða og landssvæða komu í kjölfarið. Hluti af pessari próun var sú viðleitni banka að elta viðskiptavini sína í landvinningum peirra. Ógnunin fólst í pví að bankarnir stóðu andspænis nýju umhverfi sem peir áttu erfiðara með að mæla áhættu af (Berg, 1998).

Í fyrstu olli aukning útlána engum vandræðum. Frá lokum seinni heimsstyrjaldar hafði peningastefna ríkisins veitt ákveðnum geirum atvinnulífsins stuðning með lánum á lágum vöxtum sem voru ekki í boði fyrir alla. Hátt verðbólgustig og lágt vaxtastig gerði pað að verkum að raunvaxtastig var neikvætt og pví voru lán skömmtuð af ríkinu (Jonung, 2008). Par sem lengi höfðu verið höft á útlánum hafði myndast undirliggjandi umframeftirspurn eftir lánum og pví mátti gera ráð fyrir að jafnvægispunktur útlána yrði hærri. Eftir pví sem útlánaaukning jókst hækkuðu vextir (markmiðið var að slá á eftirspurn eftir fjármagni) og leiddi pað til hærri vaxtamunar við útlönd. Lántökur í erlendri mynt urðu álitlegri og í skjóli frjáls fjárflæðis á milli landa leiddi pað til pess að peningamálastefna hinna Norðurlandanna um að hefta vöxt varð bitlausari (Honkapohja, 2009). Án fjárstreymis erlendis frá hefði pessi mikli lánavöxtur verið óhugsandi (Berg, 1998). Lántakendur mátu líkurnar á miklu tapi vegna gengissveiflna augljóslega litlar (Jonung, Kiander \& Vartia, 2008) en gjaldmiðlar Svípjóðar og Finnlands voru festir við pýska markið.

Útlánavöxtur á Íslandi tók kipp í kjölfar einkavæðingar ríkisbankanna. Íslenskir bankar og sparisjóðir höfðu áhuga á að auka markaðshlutdeild sína en próunin á hinum Norðurlöndunum hafði verið í pá veru. •að kallaði á áhættumeiri útlánastefnu, ólíkt pví sem gömlu viðskiptabankarnir höfðu stundað áður. 


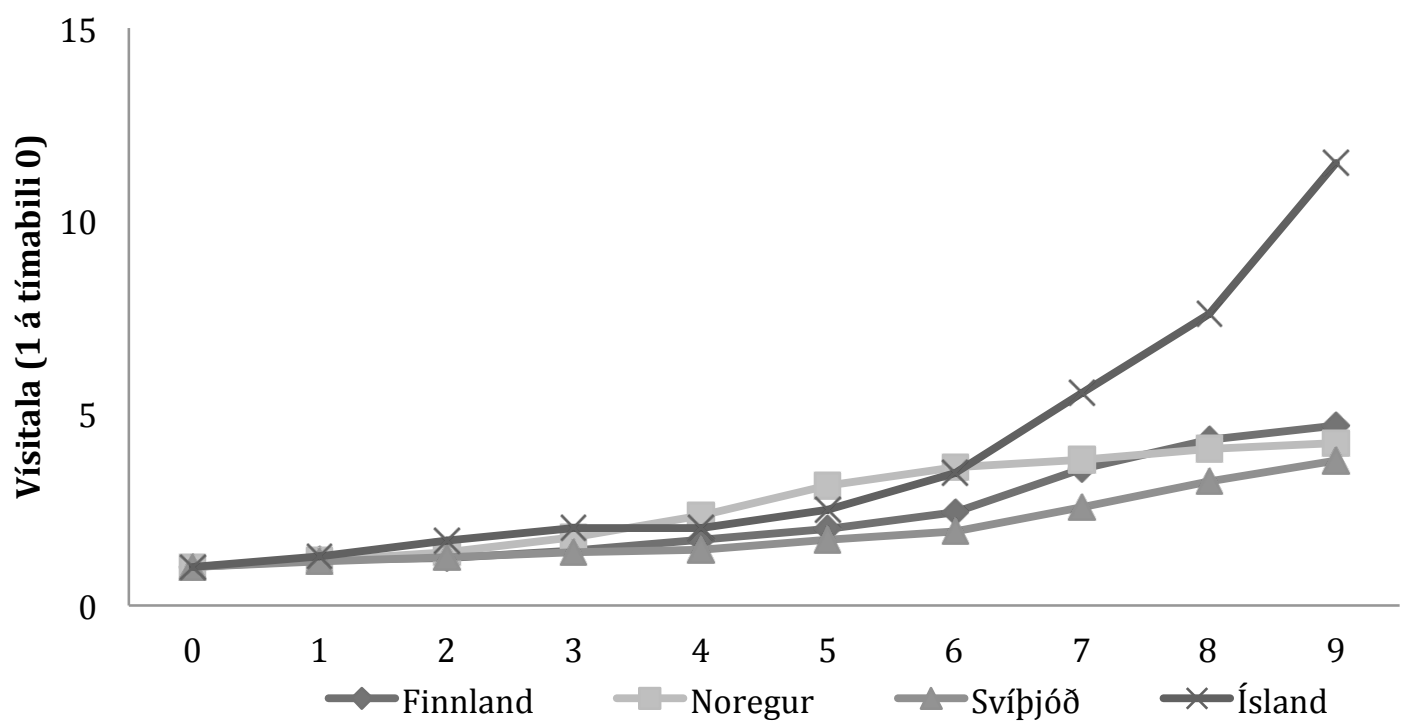

Mynd 3. Útlánavöxtur sýndur samanlagður

Heimildir: Honkapohja (2009) og Seðlabanki Íslands (2010)

Til að bera saman útlánavöxt milli Íslands og hinna Norðurlandanna er mynd 2 notuð. Upphafstímabilið, tími T, stendur fyrir árið 1999 á Íslandi og árið 1982 fyrir Norðurlöndin. Myndin sýnir að fyrra útlánavaxtartímabilið á Íslandi var hliðstætt seinna útlánavaxtartímabilinu á Norðurlöndum. Seinna útlánavaxtartímabilið á Íslandi er tvöfalt á við pað sem var á Norðurlöndunum. Í Finnlandi jukust útlánin mjög eitt árið en pað sker sig frá öðrum árum par.

Eftir einkavæðinguna varð útlánavöxtur miklu meiri á Íslandi en á hinum Norðurlöndunum. Útlán í lok árs 2007 voru fjórum sinnum pað sem pau voru í lok árs 2002. Pessa próun má sjá enn skýrar á mynd 3 sem sýnir vöxtinn samanlagðan.

Neikvæðum áhrifum afnáms regluverks á Íslandi var frestað par sem ríkið hélt eignarhaldi sínu á bönkunum fram til ársins 2003. Pannig voru hömlur fyrir hendi sem komu í veg fyrir hraðan útlánavöxt prátt fyrir frjálst flæði fjármagns. •að er ekki par með sagt að enginn útlánavöxtur hafi verið á pessum árum. Hann var til staðar enda var verið að losa um kerfi sem hafði haldið verulega aftur af útlánum til fyrirtækja og heimila.

Раð vekur sérstaka athygli að útlánavöxtur hélt áfram prátt fyrir pær hættur sem steðjuðu að í íslensku fjármálalífi árið 2006. Líklegt verður að telja að sumir pátttakendur á markaði hafi talið að par sem íslenskt fjármálalíf hafi staðið tímabundið af sér pann storm hafi hann einungis verið í vatnsglasi.

\subsection{Atvinnuleysi, VLF og eignaverðbólga}

Atvinnuleysi var að jafnaði mjög lágt á níunda áratugnum (sjá mynd 4). Í Finnlandi lækkaði pað jafnt og pétt eftir miðjan áttunda áratuginn á meðan pað jókst í Noregi, fyrst og fremst vegna lækkandi olíuverðs árið 1986 sem orsakaði niðursveiflu í norska hagkerfinu. Prátt fyrir petta fór pað ekki mikið yfir 5\% en var á sama tímabili um 3\% í Finnlandi og stöðugt undir

${ }^{3}$ Upplýsingar um útlánavöxt eru aðeins veittar fyrstu níu mánuði ársins 2008 á Íslandi. Árið 2008 er pví ekki notað í pessum samanburði. Mikil aukning á sér stað á fyrstu níu mánuðum ársins í krónum talið en höfundar áætla að veigamikil skýring sé fall krónunnar gagnvart erlendum gjaldmiðlum og að útlánavöxtur hafi í rauntölum með tilliti til verðbólgu og veikingar krónunnar verið hér um bil enginn, jafnvel neikvæður. 


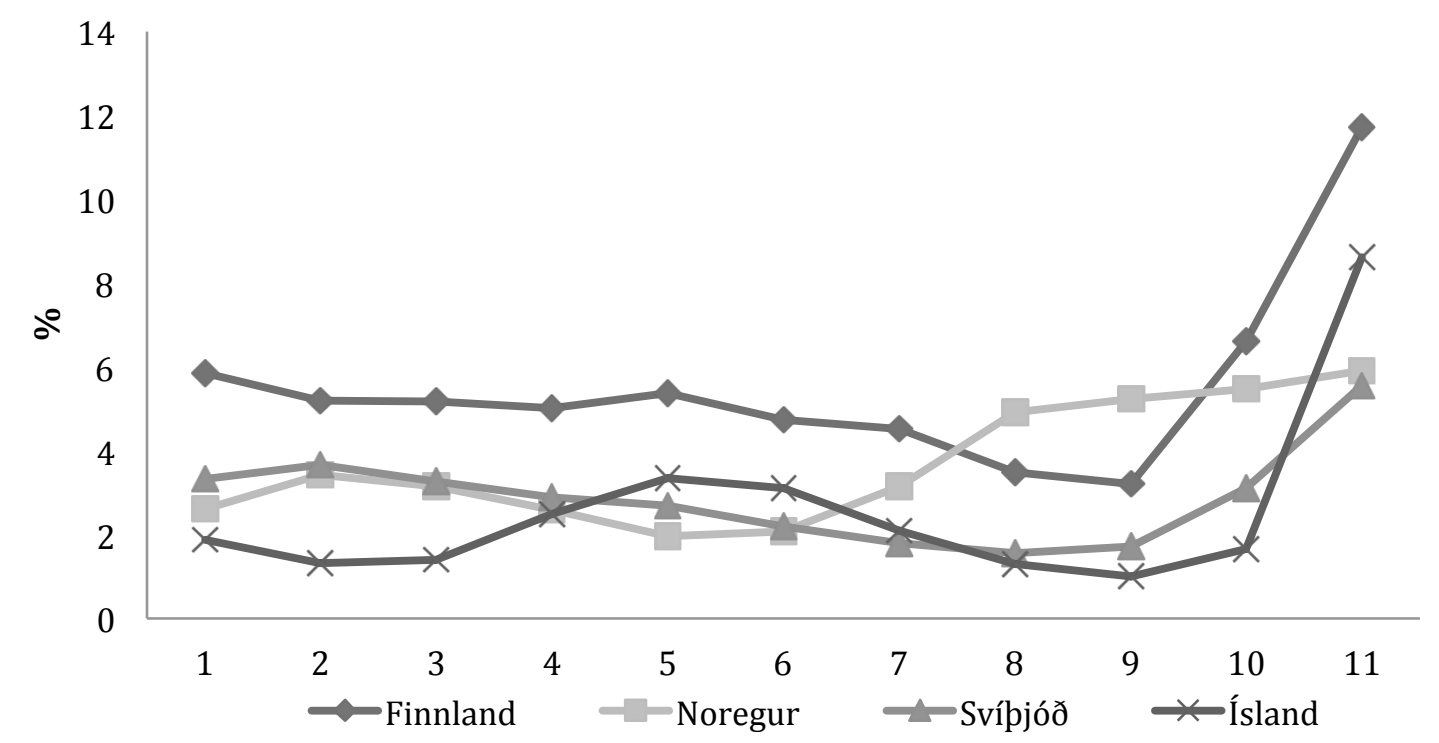

Mynd 4. Atvinnuleysi í prósentum - Ísland borið saman við Norðurlönd ${ }^{4}$ Heimild: AGS (2009b og 2010)

2\% í Svípjóð. Stefna stjórnvalda allra pessara ríkja var að tryggja fulla atvinnu (Jonung, Kiander, Vartia, 2008).

Á seinni hluta tímabilsins var afar lítið atvinnuleysi á Íslandi og skýrist pað aðallega af auknum umsvifum vegna virkjanaframkvæmda og ruðningsáhrifa peirra. Einnig var mikill uppgangur í byggingariðnaðinum. Margir innflytjendur komu til Íslands í slík störf enda fjölgaði innflytjendum á Íslandi um pað bil fimmfalt frá 1996 til 2008 (Hagstofa Íslands, 2009). Atvinnustig gefur vísbendingu um mikla penslu á pessu tímabili og prátt fyrir penslu á hinum Norðurlöndunum á samanburðartímabilinu mældist atvinnuleysi par meira en á Íslandi mestallt tímabilið. Upplýsingar frá AGS sýna að atvinnuleysi í Finnlandi fór allt upp í 17\%. Í upphafi árs 2010 mældist atvinnuleysi á Íslandi um 9\%.

Rétt eins og á hinum Norðurlöndunum hafði mikil útlánaaukning pví áhrif á efnahaginn, með atvinnuleysi á lægstu stigum samhliða miklum hagvexti. Öll löndin sýndu sterkan og stöðugan hagvöxt á tímum uppsveiflunnar, pó sérstaklega Ísland sem sýndi að meðaltali $4 \%$ árlegan hagvöxt um tíu ára skeið. Á mestu uppgangsárunum, 2003-2007, var meðaltalið rúmlega $6 \%$ (sjá mynd 5).

Próun hagvaxtar svipar augljóslega til próunar á aukningu útlána. Hagvöxtur á Íslandi fellur mikið á tímabili 4 í kjölfar hjöðnunar á tæknibólunni í upphafi áratugarins og alpjóðlegs samdráttar. Hagvöxturinn fer aftur á móti á flug samhliða auknu fjárflæði innan hagkerfisins.

${ }^{4}$ Hér eru ellefu tímabil notuð til að sýna afleiðingar aukins atvinnuleysis í kjölfar hrunsins sem átti sér stað á öllum landssvæðum. Síðasta tímabilið fyrir Ísland er áætlun AGS um atvinnuleysi á Íslandi árið 2009.

${ }^{5}$ Sýnd eru ellefu tímabil svo að hægt sé að sjá vægi niðursveiflunnar, síðasta tímabil fyrir Î́sland er áætlun AGS. 


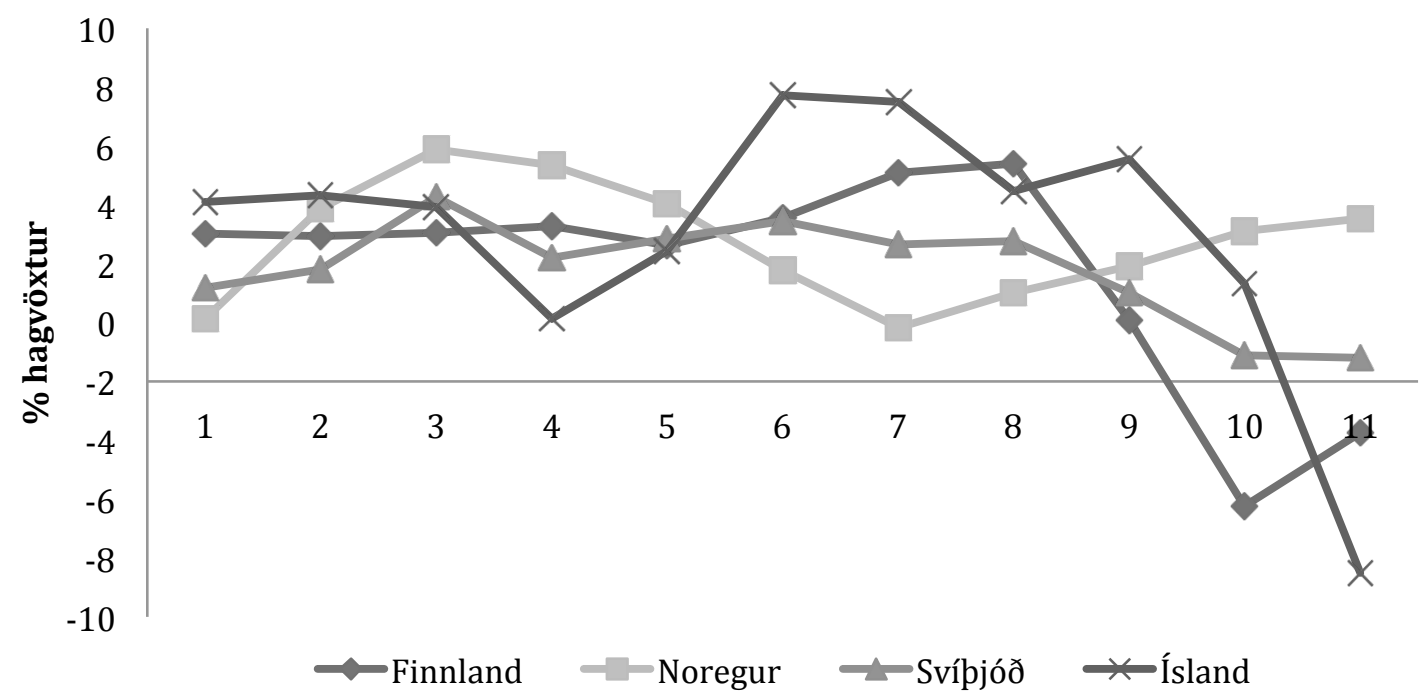

Mynd 5. Hagvöxtur á Íslandi borið saman við hin Norðurlöndin ${ }^{5}$ Heimild: AGS (2009b og 2010)

Lágt stig atvinnuleysis og hár hagvöxtur getur leitt til hárrar verðbólgu. Pessi próun virðist ekki hafa átt sér stað á hinum Norðurlöndunum. Hins vegar ber að hafa í huga að á meðan norrænu ríkin ofhitnuðu getur verið að sterkur gjaldmiðill peirra (tengdur við pýska markið) hafi dulið raunverulega eignaverðbólgu. Innflæði fjármagns til Íslands gerði pað að verkum að íslenska krónan styrktist vegna sömu áhrifa.

Samanburður á verðbólgu, sýndur á mynd 6, ber með sér frekar lága verðbólgu á Íslandi meðan á uppsveiflu stóð. Á pessum tíma var markmiðum Seðlabankans um 2,5\% verðbólgu pó afar sjaldan náð. Verðbólga var jafnframt dulin vegna mjög sterkrar íslenskrar krónu sem gerði innfluttar vörur ódýrar. Рað voru pví innlendir pættir sem fyrst og fremst voru áhrifavaldar aukinnar verðbólgu.

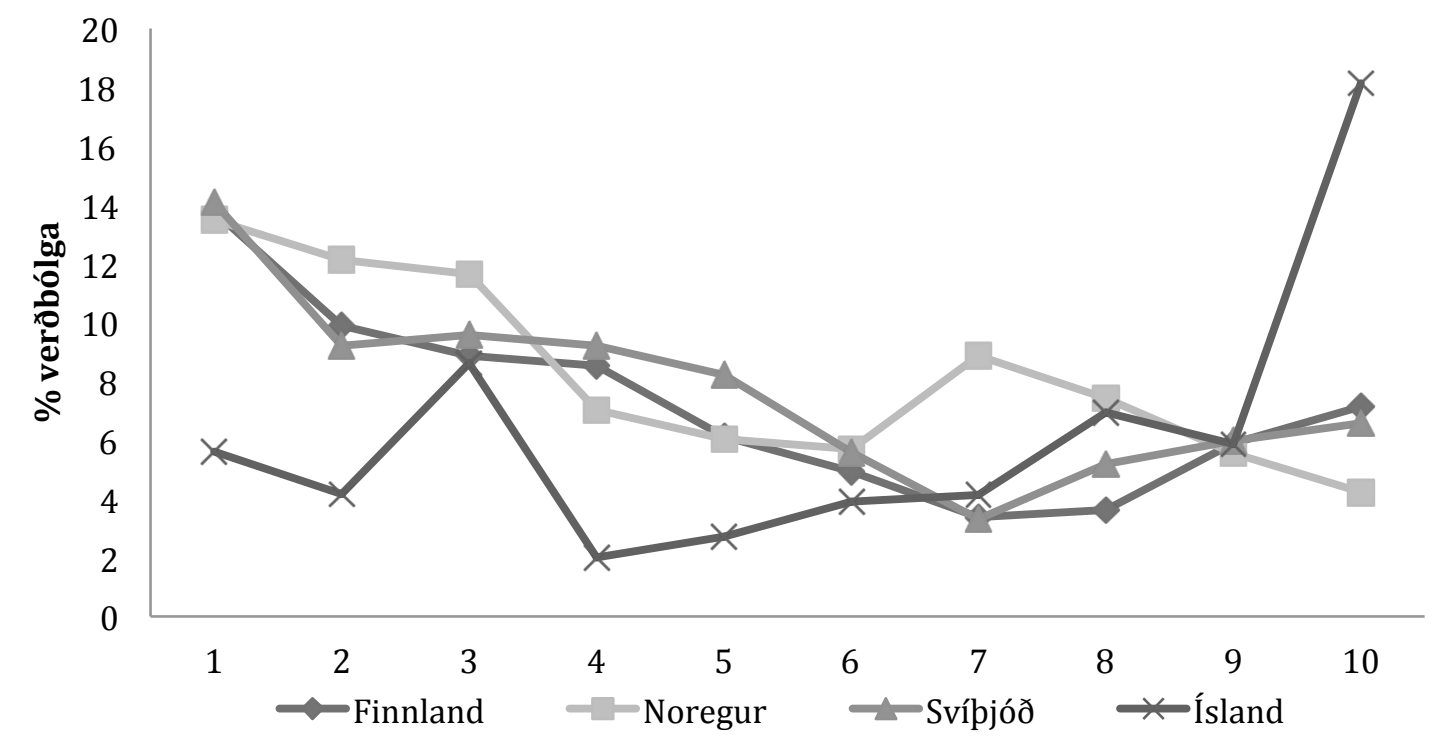

Mynd 6. Verðbólga \% (í lok árs) - Ísland borið saman við hin Norðurlöndin Heimild: AGS (2009b og 2010) 


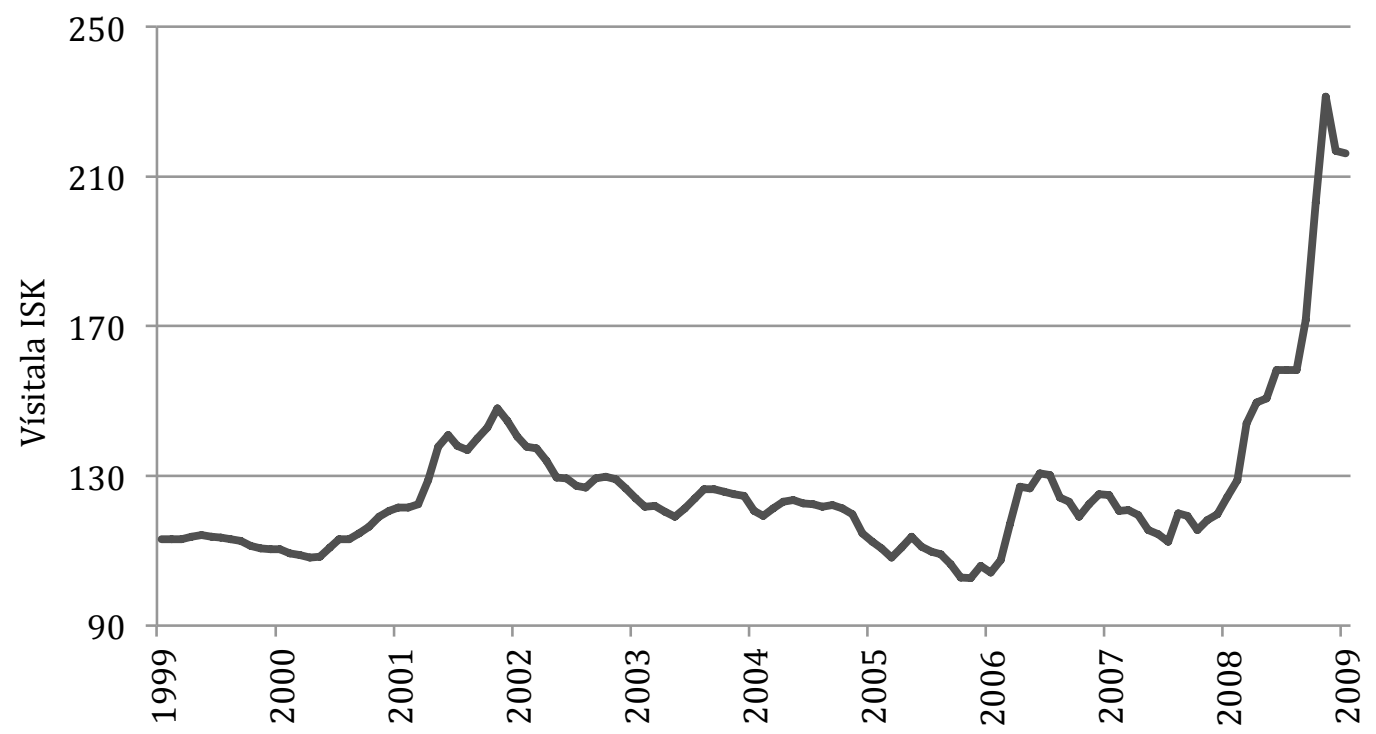

Mynd 7. Próun íslensku krónunnar 1999-2009 Heimild: Seðlabanki Íslands (2009)

Pegar íslenska krónan féll fór verðbólga hratt upp. Sterk króna, sem hafði haldið aftur af verðbólgu, hrundi í kjölfar falls bankanna (hún hafði pó veikst talsvert nokkur misserin á undan). Petta skýrir hið mikla verðbólguskot í kjölfarið. Eins og mynd 7 ber með sér féll íslenska krónan skart. Рað olli pví að innfluttar vörur hækkuðu í verði og hugsanlegt rými smásala til að taka á sig einhvern mismun á gengissveiflum hvarf fljótt; veiking krónunnar fór pví hratt út í verðlag. Svipuð próun átti sér stað á hinum Norðurlöndunum pegar tenging gjaldmiðlanna var afnumin en par sem um handstýringu var að ræða á samanburður síður við.

Verðbólgumæling á íbúðarhúsnæði gæti pví verið betri mælikvarði á eignaverðbólgu enda tekur hún bæði tillit til áhrifa almennrar verðbólgu og aukningar í virði eigna (p.e. eignabólu ef hún er til staðar). Рað er almennt viðurkennt að helsta ástæða pess að minnkun hafta hafi orsakað verðbólgu sé hækkandi eignaverð en petta er pó nokkur einföldun (Englund, 1999). Fasteignaverð í Svípjóð var t.d. að mestu stöðugt eða lækkaði stærstan hluta níunda áratugarins (Berg, 1998). Pað var ekki fyrr en lánin fóru úr 75\% í 90\% markaðsverðmætis eigna (e. Loan-To-Value) árið 1988, premur árum eftir losun regluverks, að fasteignaverð hækkaði um 35\% (Englund, 1999). Englund sýnir fram á að hærra hlutfall lána á móti markaðsverðmæti sé mælikvarði á áhættusækni enda var lánshlutfallið lækkað á nýjan leik árið 1991 og enn frekar árið 1992. Svíar ákváðu að lækka lánshlutfallið á sama tíma og nauðsynlegt var að fá aukna innspýtingu í gangverk pjóðfélagsins (Englund, 1999). Ákvörðunin er vísbending um að Svíar hafi lært af reynslunni að 90\% lánshlutfall til íbúðakaupa væri of hátt, jafnvel á krepputímum. Pessi próun á fasteignaverði pýðir að aðhald ríkisins verður að vera til staðar í kjölfar minnkandi áherslu á regluverk. Án slíks aðhalds er hætta á að útlán fari úr böndunum. 


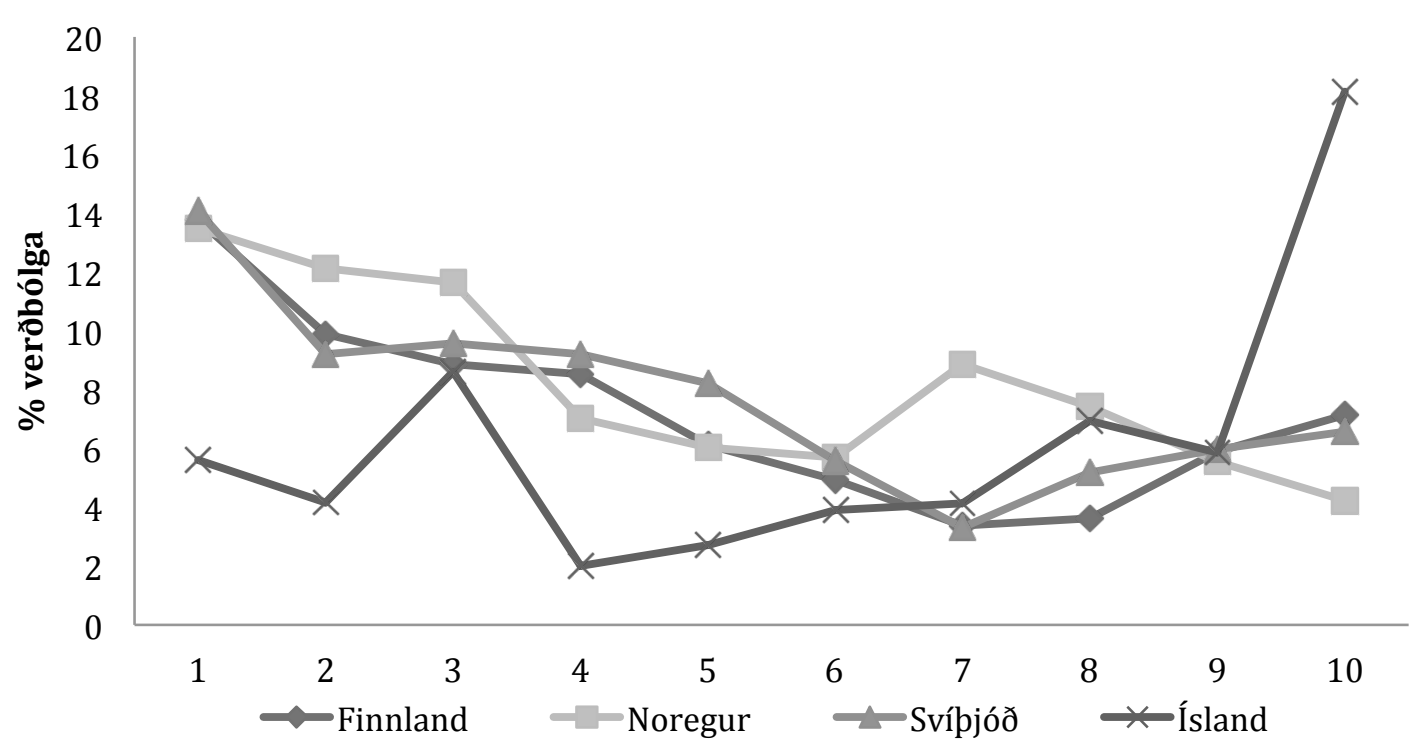

Mynd 8. Samanburður á fasteignaverðbólgu (Vísitala sett á 100 í upphafi) Heimild: Berg (1998) og Fasteignaskrá ríkisins (2009)

Á Íslandi gerðust hlutirnir að sumu leyti með ólíkum hætti. Hámark lána sem hlutfall af markaðsverðmæti fasteigna hækkaði samfara auknum efnahagsumsvifum. Íbúðalánasjóður hafði einokað lánveitingar vegna íbúðarhúsnæðis og naut niðurgreiddra kjara vegna eiganda síns, íslenska ríkisins. Peir vextir sem Íbúðalánasjóður bauð voru lægri en bankar og sparisjóðir gátu boðið en lán peirra voru aðeins samkeppnishæf pegar að lántaki purfti lán umfram hámark Íbúðalánasjóðs. Pegar ríkið ákvað að hækka hámark lána sem hlutfall af markaðsverðmæti eigna úr 65\% upp í 90\% kom Kaupping inn á íbúðalánasjóðsmarkaðinn af fullum punga. Petta var í ágúst 2004. Flest önnur fjármálafyrirtæki fylgdu í kjölfarið. Í staðinn fyrir að takmarka niðurgreidd lán var aðgangur að peim nánast opnaður upp á gátt. Skattaívilnanir í formi vaxtabóta til peirra sem mest skulduðu hvöttu jafnframt til lántöku. Раð var pví freistandi fyrir marga að taka heldur hærri lán en lægri. Misvægi hafði verið komið á milli aðhaldssamrar vaxtastefnu Seðlabanka Íslands og mikils framboðs fjármagns frá bönkum og stjórnvöldum.

Í peim tilgangi að ná sem mestri markaðshlutdeild fóru bankarnir fram úr hámarki Íbúðalánasjóðs. Um stund fór Glitnir upp í 100\% lán. Samkeppnin varð svo hörð að bankarnir töpuðu í raun á lánveitingum til kaupa á íbúðarhúsnæði, einfaldlega vegna vaxtamunarins (p.e.a.s. vegna neikvæðs sambands fjármögnunar og lánveitinga). Pað er vafamál hvort peir hefðu nokkru sinni getað haft hagnað af pessum lánveitingum til lengri tíma litið. Sparisjóður Hafnarfjarðar seldi t.a.m. skuldabréf á vaxtabilinu 4,90\% til 5,20\% en lánaði til viðskiptavina sinna vegna húsnæðiskaupa á 4,15\% vöxtum (Baldur Thorlacius, munnleg heimild, 18. ágúst 2009). Framan af hækkaði fasteignaverð á Íslandi með sambærilegum hætti og í Finnlandi (mynd 8). Ísland á sér pó mun lengra tímabil hækkandi fasteignaverðs sem pýðir að verðið var annaðhvort óeðlilega lágt í upphafi samanburðartímabils eða óeðlilega hátt í lok pess.

Раð var ákveðinn forleikur að ofangreindri próun. Árið 2003 lækkaði Seðlabanki Íslands bindiskylduhlutfall banka til samræmis við pað sem pekktist á meginlandi Evrópu, að kröfu íslenskra fjármálafyrirtækja sem töldu sig ekki njóta sömu starfsskilyrða og erlendir samkeppnisaðilar peirra. Greiningardeild Kauppings áætlaði í skýrslu, í lok maí árið 2004, 


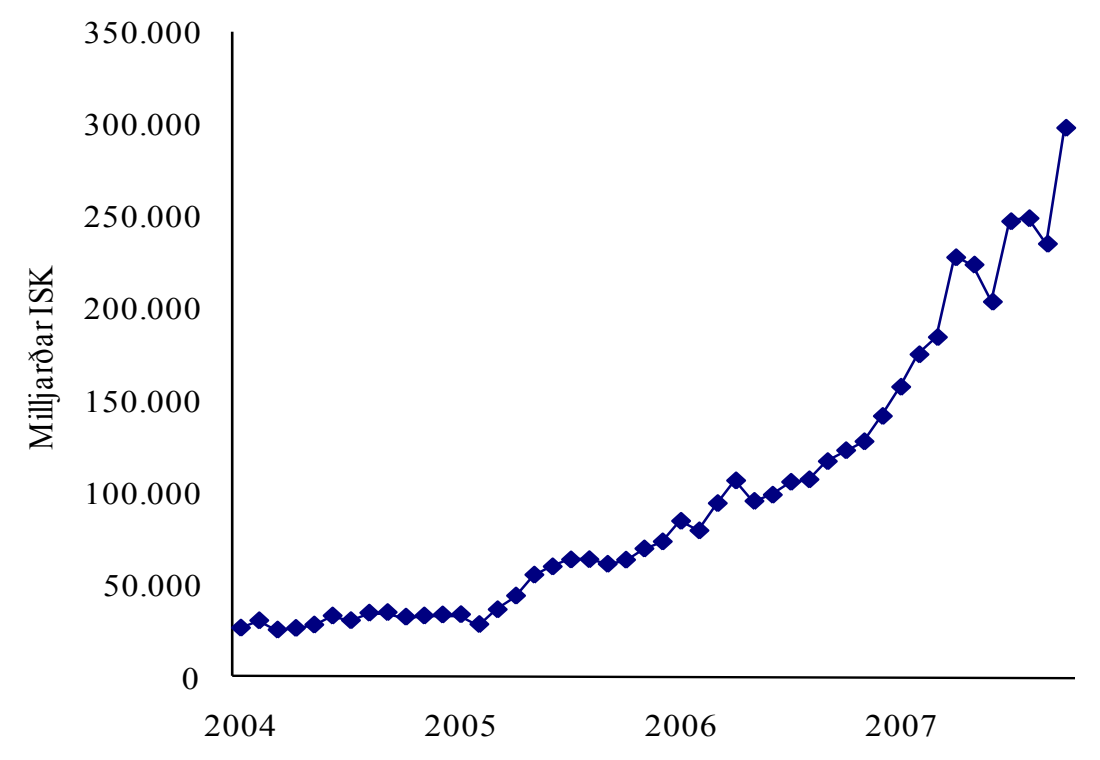

Mynd 9. Skuldir heimila í erlendri mynt mælt í íslenskum krónum Heimild: Seðlabanki Íslands 2009

að lækkun bindiskyldunnar hefði losað um 20 milljarða í bankakerfinu sem gátu mögulega nýst til útlána (Sérefni - Efnahagsmál). Petta var tæpum fjórum mánuðum áður en sami banki fór inn á íbúðalánamarkað. Með lækkun bindiskyldu og auknu aðgengi fólks að fjármagni var pví verið að kynda undir hagkerfinu á sama tíma og stýrivextir fóru að hækka. Líklegast hefur stemning pjóðfélagsins verið á peim nótum að erfitt hefði verið að hækka bindiskylduna og lækka lánshlutföll á nýjan leik.

Pegar hagkerfi ofhitnar eins og hér hefur verið lýst verður upplifun almennings af velgengninni til pess að afleidd áhrif verða frekari tiltrú á aukna auðsæld. Hækkun eigna verður til pess að fólki finnst pað vera ríkara. Sú tilfinning leiðir til aukinnar einkaneyslu og hvatning til sparnaðar minnkar par sem eignir fólks (í gegnum ávöxtun og eignir í lífeyrissjóðum) aukast enn hraðar. Hringrás er komin af stað par sem neysla er orðin meginkraftur aukins hagvaxtar; neysla sem ekki fær staðist til lengri tíma. Raunar var sparnaðarhlutfall pjóðarinnar, pað er hlutfall nettó sparnaðar af vergri pjóðarframleiðslu, neikvætt allt uppgangstímabilið 2003 til 2007 (Carey, 2009).

Til að bæta gráu ofan á svart tóku lántökur Íslendinga í erlendri mynt flugið árið 2006. Slíkar skuldir voru orðnar 14\% af skuldum heimila í upphafi árs 2008 (Carey, 2009). Mynd 9 sýnir fjórföldun í lántöku, mælt í íslenskum krónum. Íslensku bankarnir voru almennt hættir að lána í erlendri mynt undir lok árs 2007 en engu að síður tvöfölduðust skuldir í erlendri mynt árið 2008 vegna falls íslensku krónunnar. Hliðstæð próun átti sér stað á hinum Norðurlöndunum; án erlends fjármagns hefði hin gríðarlega aukning skuldsetningar ekki verið möguleg (Berg, 1998). Lán í erlendri mynt jukust úr 27\%, sem hlutfall heildarlána innan bankakerfisins árið 1985, í 47,5\% árið 1990 (Englund 1999).

Lánveitingar tengdar erlendum myntum voru auk pess áhættumiklar fyrir banka. Pó svo að bankarnir hafi keypt varnir gagnvart gengissveiflum gerði misvægi í bindistíma fjármögnunar og lánveitinga pað að verkum að skyndileg veiking krónunnar dró úr mætti slíkra varna; ${ }^{6}$ breytingin á gengi gjaldeyris magnaðist vegna lána til langs tíma en varnirnar

6Banki sem lánar peninga til langs tíma í erlendri mynt, fjármagnaða með innlendri mynt, getur ekki keypt gjaldeyrisvarnir nema til skamms tíma. 
náðu aðeins til skamms tíma. Carey hjá OECD (2009) og Jännäri (2009) benda auk pess á að pó að bankar hafi varið sig gegn gjaldeyrissveiflum hafi viðskiptavinirnir sjaldnast verið með slíkar varnir.

\section{Niðurstaða}

Helstu einkenni bankakreppunnar í Svípjóð og Finnlandi eru svo lík að kreppurnar hafa oft verið kallaðar tvíburakreppur (Jonung, Kiander \& Vartia, 2008). Samanburður á tímabilum í aðdraganda hruns á milli Norðurlanda og Íslands gefa tilefni til að bæta Íslandi við pessa jöfnu pannig að um sé að ræða „príburakreppu“, svo líkar voru aðstæður í Svípjóð og Finnlandi peim aðstæðum sem priðja „barnið“ gekk í gegnum tuttugu árum síðar. Niðurstöður pessarar rannsóknar benda til að Ísland hafi pó verið pað barn sem hagaði sér sýnu verst. Pau sameiginlegu stef undanfara bankakreppu sem Reinhart og Rogoff (2009) lýsa eiga við um Ísland. Í peim felst mikil lántaka, hvort sem er hjá ríki, bönkum, fyrirtækjum eða einstaklingum sem oft felur í sér kerfisbundnari hættur en pær sem virðast vera fyrir hendi á uppgangstímum.

\section{1 Áhrif vegna afnáms regluverks}

Mikið hefur verið rætt um að afnám regluverks hafi verið helsta ástæða fjármálakreppu Norðurlandanna. Englund (1999) telur pá skoðun pó vera einföldun á raunveruleikanum. Útlánavöxtur hafi ekki farið almennilega af stað fyrr en lánshlutföll voru hækkuð á hinum Norðurlöndunum og svipuð próun átti sér stað á Íslandi.

Niðurstaða rannsóknar Demirgüç-Kunt og Detragiache (1998) á fylgni bankakreppa og hafta í bankageiranum bendir til pess að líkur á fjármálakreppu séu meiri par sem höftin eru minni. Hins vegar er ekki, sögulega séð, fylgni á milli fjármálakreppa og breytinga frá umhverfi hafta til losunar regluverks að mati Demirgüç-Kunt og Detragiache; almennt myndist óstöðugleiki í fjármálakerfinu ekki fyrr en nokkrum árum síðar. Gögn peirra gefa til kynna að meiri líkur séu á bankakreppum par sem regluverk er veikt, spilling almenn og stjórnsýsla veikburða. Með öðrum orðum: Séu framangreindir pættir í lagi minnka líkurnar á bankakreppu. Englund (1999) kemst að peirri niðurstöðu að jafnvægi í efnahagslegu umhverfi sé að verða mikilvægari páttur í að tryggja stöðugleika á fjármálamörkuðum.

раð er með svipuðum hætti einföldun að halda pví fram að afnám regluverks hafi eitt og sér valdið hruninu á Íslandi. Í báðum tilfellum var pað ekki afnám regluverks sem skóp útlánavöxtinn heldur má segja að slíkt afnám hafi opnað dyr fyrir óhóflegum útlánavexti. Раð var ekki fyrr en aðhald í peningastefnu minnkaði eða ójafnvægi í efnahagslífinu varð til sem dyrnar voru opnaðar upp á gátt, bæði í tilfelli hinna Norðurlandanna á níunda áratugnum og nýverið á Íslandi. Á Norðurlöndunum var pað hækkun lánshlutfalls til íbúðakaupa sem kom útlánaskriðunni af stað. Á Íslandi var auðveldari aðgangur að lánsfé til íbúðakaupa páttur í aukningu útlána en lækkun bindiskylduhlutfallsins jók einnig fjármagn í umferð sem bankar gátu skyndilega lánað. Óhófleg útlán voru aftur á móti að mestu leyti takmörkuð við fasteignakaup á Norðurlöndunum en á Íslandi voru slíkar takmarkanir síður sýnilegar. Aukin áhættusækni í útlánum átti sér stað á báðum samanburðartímabilum. Sú aukna áhættusækni var umfangsmeiri á Íslandi í skjóli lágs vaxtastigs á alpjóðlegum vettvangi og greiðs aðgangs að fjármagni. 


\subsection{Breyttur tídarandi í bankastarfsemi}

Bæði Ísland og hin Norðurlöndin nutu offramboðs fjár á uppgangstímanum. Vöxtur útlána var pó miklu meiri á Íslandi eins og mynd 2 sýnir. Nýlegar upplýsingar (sjá til dæmis lánabók Kaupthings) gefa til kynna að lánveitingar íslenskra banka hafi ekki aðeins verið illa ígrundaðar heldur jafnvel á mjög gráu svæði par sem veð fyrir lánum voru lág í hlutfalli við lánsupphæðir. Verðbréfin sem kaupa átti voru jafnvel einfaldlega einu veðin.

Útlánavöxtur á Norðurlöndunum orsakaðist aðallega af eignaverðbólgu. Á Íslandi voru pað hins vegar óhyggilegar lánveitingar sem stóðu að baki stórum upphæðum. Slíkar lánveitingar tengdust oft krosseignarhaldi eða öðrum tengslum manna á milli par sem veðin voru afar vafasöm (Jännäri, 2009). Petta var ekki talið veigamikið vandamál á Norðurlöndunum (Jonung, 2008).

Meginhluti hárra lánveitinga íslensku bankanna var til eignarhaldsfélaga sem fjárfestu mikið í hlutabréfum eða notuðu lánin sem áhættufjármagn í ný verkefni. Minnir petta ópægilega á próunina í Japan á níunda áratugnum (Chancellor, 2000). Veðin voru einna helst hlutir í peim félögum sem fjárfest var í (Jännäri, 2009). Mörg lánanna voru kúlúlán sem pýddi að lántakinn purfti hvorki að greiða vexti né höfuðstól fyrr en í lok samningstímans.

Mismunurinn á milli tímabila kom í framhaldi af meiri trú fólks á kapítalisma. Рað var almennt viðurkennt eftir fall járntjaldsins að kommúnismi hefði tapað og stefna kapítalsmans unnið (Shiller, 2001). Afnám Glass-Steagall laga árið 1999, par sem múrar á milli viðskiptabankapjónustu og fjárfestingarbanka voru rifnir niður, gerði pað að verkum að starfsumhverfi íslenskra banka hafði meira rými til vaxtar en norrænir bankar tæpum 20 árum áđur. Pessi próun hafði áhrif á vöxt íslensku bankanna (Ásgeir Jónsson, 2009) sem uxu í anda fjárfestingarbanka. Ríkisábyrgð var á innstæðum að ákveðnu marki og voru pær ekki aðeins notaðar til að fjármagna hefðbundin útlán heldur einnig lán sem í mörgum tilvikum voru áhættusöm.

\subsection{Ríkisfjármál og peningamálastefna}

Margir fræðimenn gagnrýna að gengi norrænu gjaldmiðlanna hafi verið fest við pýska markið (Jonung, 2008; Honkapohja \& Koskela, 2000; Englund, 1999). Flestir eru peirrar skoðunar að gengið hefði átt að fljóta pannig að pað gæfi eftir. Honkapohja og Koskela (2000) segja til að mynda að haldi peningamálastjórnun ekki aftur af penslu vegna innflæðis fjármagns purfi að leyfa genginu að fljóta.

Reynsla Íslands sýnir hins vegar hið gagnkvæma. Íslensku krónunni var leyft að fljóta við kringumstæður par sem Seðlabanki Íslands ákvarðaði vexti til að halda verðbólgu innan 2,5\% marka. Pessi viðleitni missti marks eins og mynd 8 sýnir (verðbólga). Að halda úti pessu markmiði meðan frjálst flæði fjármagns var leyft breytti landslagi framboðs og eftirspurnar fjármagns. Pegar Seðlabankinn hækkaði vexti 2004 - 2008 flæddi fjármagn inn í landið, fyrst og fremst fyrstu árin, og styrkti gengi íslensku krónunnar í andstöðu við almennar kenningar. Petta olli verðlækkunum á innfluttum vörum sem hélt uppi neyslu (Jännäri, 2009). Auk pess jókst fjármagn í umferð við lækkun bindiskyldunnar (Kaupping, 2004). Svipað norrænu pjóðunum tóku Íslendingar í síauknum mæli lán í erlendri mynt og komust pannig hjá hækkandi innlendum vöxtum. Í raun leiddi petta ekki aðeins til bitlausrar peningamálastefnu Seðlabankans heldur jók auðveldur aðgangur að erlendu fjármagni verðbólguprýsting (Jännäri 2009). Pví felst engin töfralausn í pví eingöngu að leyfa genginu að fljóta. 
Reynsla Íslands og Norðurlanda gefur til kynna að ríkisfjármál og peningamálastefna purfi að viðhalda sömu markmiðum. Verðbólgumarkmið með stýringu vaxtastigs og frjáls flæðis fjármagns var stefna Íslands en Norðurlöndin festu gjaldmiðla sína og notuðu vaxtastig til að hafa stjórn á hagkerfinu. Sagan sýnir að báðar pessar leiðir verða bitlausar um leið og spákaupmennska á tímum eignaverðbólgu grefur um sig. Íslendingar gátu fjármagnað fjárfestingar sínar og neyslu með lánum í erlendri mynt (Reinhart og Rogoff, 2009). Raunverulegt vaxtastig var dulið en pað skipti minna máli á tímum mikilla eignaverðhækkana. Í undanfara hrunsins árið 1929 var vaxtastig á sumum lánum til hlutabréfakaupa allt að 40-50\% með auknum kröfum um veðhlutföll (Rappoport \& White, 1994). Spákaupmennska upp á krít jókst samt sem áður par sem hlutabréfamarkaðurinn var orðinn pungamiðja í samfélagslegu samhengi (Galbraith, 1997).

Á meðan Seðlabankinn hækkaði vexti til að slá á ofvöxt í hagkerfinu hækkaði ríkisvaldið hámarksupphæð lána og lánsfjárhlutfall, lækkaði skatta, hélt skattaívilnunum og hóf gríðarstórar framkvæmdir sem námu 10,5\% til 12,5\% af VLF árin 2005 og 2006 (Seðlabanki Íslands, 2009). Skattalækkanir árið 2007 voru eins og olía á eld aukins aðgangs að fjármagni, rétt eins og 80 árum áður í Bandaríkjunum pegar seðlabanki Bandaríkjanna lækkaði stýrivexti (Fridson, 1998).

\section{Samantekt}

Í inngangi pessarar greinar var peirri spurningu varpað fram hvort stormurinn sem skall á Íslandi hafi verið fyrirsjáanlegur. Greiningin sýnir að viðvörunarljósin loguðu víða. Jafnframt sýnir samanburðurinn við hin Norðurlöndin að margt hefði getað gefið tilefni til pess að ætla að djúp kreppa væri í aðsigi á Íslandi. Efnahagslegir pættir sem snerta söguna, svo og félagslegir og sálfræðilegir pættir, hafa verið bakgrunnur pessarar greiningar. Líkt og Galbraith (1997) heldur fram er bragurinn í hverju samfélagi stór áhrifavaldur pess hvernig bólur verða til. Hann bendir á að oft hafi aðgangur að lánsfé verið auðveldur án pess að bólur hafi myndast. Niðurstöður pessarar rannsóknar gefa til kynna að mismunur á útlánapenslu Norðurlandanna árin 1982-1990 og Íslands 1999-2007 sé pað mikill að aðgangur að fjármagni geti vart verið eina skýringin. Fleiri pættir koma til, nokkrir eru lagðir fram sem útskýringar í niðurstöðukaflanum. Rannsóknir á pessum sviðum gætu gefið fyllri mynd af pví hvers vegna viðvörunarljósin voru hunsuð.

\section{Heimildir}

Alpjóðagjaldeyrissjóðurinn. (2008). IMF Executive Board Concludes 2008 article IV consultation with Iceland. (Rannsóknarskýrsla nr. 08/120). Sótt 11. september 2009 af http://www.imf.org/external/np/sec/pn/2008/pn08120.htm.

Alpjóðagjaldeyrissjóðurinn. (2009a). Iceland: Staff report for first review under stand-by arrangement and requests for extension of the arrangement, waivers of nonobservance of performance criteria, and rephrasing of access. Sótt 7. nóvember 2009 af http://www.imf.org/external/pubs/ft/scr/2009/cr09306.pdf

Alpjóðagjaldeyrissjóðurinn. (2009b). Gross domestic product, constant prices. Sótt 6. júlí 2009 úr World Economic Outlook Database. 
Alpjóðagjaldeyrissjóðurinn. (2010). Gross domestic product, constant prices. Sótt 12. febrúar 2010 úr World Economic Outlook Database.

Ásgeir Jónsson. (2009). Why Iceland? New York: McGraw-Hill.

Berg, S. (1998). Bank failures in Scandinavia. Í J. E. Huges og S. B. MacDonald (ritstjórar), International banking: Text and cases (bls. 198-207). New Jersey: Pearson Education Asia Limited and Tsinghua University Press.

Booth, P. (2009). Introduction. Í P. Booth (ritstjóri), Verdict on the crash: Causes and policy implications (bls. 27-35). London: The Institute of Economic Affairs.

Buttler, E. (2009). The financial crisis: Blame governments, not bankers. Í P. Booth (ritstjóri), Verdict on the crash: Causes and policy implications (bls. 51-57). London: The Institute of Economic Affairs.

Carey, D. (2009). Iceland: The financial and economic crisis. Economics Department Working Paper, nr. 725. Sótt 7. nóvember 2009 af http://www.olis.oecd.org/olis/2009doc.nsf/LinkTo/NT000069D2/\$FILE/JT03271463.PDF

Chancellor, E. (2000). Devil take the hindmost: A history of financial speculation. New York: Plume.

Danske Bank. (2006). Iceland: Geysir crisis. Sótt 6. febrúar 2010 af http://www.mbl.is/media/98/398.pdf

Demirgüç-Kunt, A. og Detragiache, E. (1998). Financial liberation and financial fragility. Sótt 10. mars 2010 af http://siteresources.worldbank.org/DEC/Resources/847971251813753820/6415739-1251813951236/demirguc.pdf

Englund, P. (1999). The Swedish banking crisis: Roots and consequences. Oxford Review of Economic Policy, 15(3), 80-97.

Englund, P. og Vihriala, V. (2003). Financial crises in developed economies: The cases of Sweden and Finland. Stockholm: Handelshögskolan.

Fasteignaskrá ríkisins. (2009). Vísitala íbúðaverðs. Sótt 2. febrúar 2010 af http://www3.fmr.is/Markadurinn/ /chart/3

Fjármálaeftirlitið. (2008). Stress test. Sótt 20. ágúst 2009 af http://www.fme.is/?PageID=168

Fjármálaeftirlitið. (2009a). Ársskýrsla. Sótt 5. september 2009 af http://fme.is/?PageID=531

Fjármálaráðuneytið. (2009). Eignir og skuldir ríkissjóðs 1998-2010. Sótt 24. janúar 2010 af http://www.fjarmalaraduneyti.is/media/Lanamal/Eignir_og_skuldir_rikissjods_1998_201 $\underline{0 . p d f}$

Fjármálaráðuneytið. (2010). Um skuldastöðu ríkissjóðs. Sótt 15. mars 2010 af http://www.fjarmalaraduneyti.is/frettir/frettatilkynningar/frettatilkynningar/nr/12988

Fridson, M. S. (1998). It was a very good year: Extraordinary moments in stock market history. New York: John Wiley \& Sons.

Galbraith, J. K. (1997). The great crash. New York: Mariner Books.

Gregg, S. (2009). Moral failure: Borrowing, lending and the financial crisis. Í P. Booth (ritstjóri), Verdict on the crash: Causes and policy implications (bls. 145-152). London: The Institute of Economic Affairs.

Hagstofa Íslands. (2009). Mannfjöldi eftir uppruna, kyni, aldri og ríkisfangi 1996-2009. Sótt 30. janúar, 2010 úr gagnagrunni Hagstofu Íslands um ríkisfang, fæðingarland og uppruna íbúa.

Hagstofa Íslands. (2010). Landsframleiðsla og pjóðartekjur 1980-2008. Sótt 15. febrúar 2010 úr gagnagrunni Hagstofu Íslands um pjóðhagsreikninga.

Honkapohja, S. (2009). The 1990's financial crises in Nordic countries. Bank of Finland Research Discussion Papers, 5, 7-26. 
Honkapohja, S. og Koskela, E. (2000). The economic crisis of the 1990s in Finland. Helsinki: University of Helsinki and CEPR.

Jännäri, K. (2009). Report on banking regulation and supervision in Iceland: Past, present and future. Sótt 15. júlí 2009 af

http://eng.forsaetisraduneyti.is/media/frettir/KaarloJannari_2009.pdf

Jonung, L. (2008). Lessons from financial liberalisation in Scandinavia. Comparative Economic Studies, 50, 564-598.

Jonung, L. (2009). The Swedish model for resolving the banking crisis of 1991-93. Seven reasons why it was successful. European Economy Economic Papers, 360, 1-27.

Jonung, L., Kiander J. og Vartia, P. (2008). The great financial crisis in Finland and Sweden: The dynamics of boom, bust and recovery, 1985-2000. European Economy Economic Papers, $350,1-70$.

Josefsson, M. (2009). Viðtalið. Ríkissjónvarpið, 15. nóvember. Sótt 10. mars 2010 af http://http.ruv.straumar.is/static.ruv.is/geyma/vidtalid/josefsson15.11.2009.wmv

Kaupping. (2004). Peningar, bankar og verðbólga. Sótt 30. janúar 2010 af http://www.kbbanki.is/Uploads/FileGallery/Serefni/Serefni280504.pdf

Kirkpatrick, G. (2009). The corporate governance lessons from the financial crisis. Sótt 9. september 2009 af http://www.oecd.org/dataoecd/32/1/42229620.pdf

Kamallakharan, Bala. og Helgi Tómasson. (2009). Can power law help us avoid the high impact tail events? Í Ingjaldur Hannibalsson (Ritstjóri), Rannsóknir í Félagsvísindum $\mathrm{X}$ (bls. 77-88). Reykjavík: Félagsvísindastofnun Háskóla Ísland.

Már Guðmundsson. (2010). The financial crisis in Iceland and the fault lines in cross border banking. Sótt 5. febrúar 2010 af http://sedlabanki.is/?PageID=13\&NewsID=2361

Morgunblaðið. (2009, 19. janúar). Voru í raun án Seðlabanka. Sótt 15. febrúar 2010 af http://www.mbl.is/mm/frettir/innlent/2009/01/19/voru_i_raun_an_sedlabanka/

Portes, R. og Baldursson, F. M. (2007). The internationalization of Iceland's financial sector, Reykjavík: Viðskiptaráð Íslands.

Rappoport, P. og White, E. N. (1994). Was the crash of 1929 expected? The American Economic Review, 84(1), 272-282.

Reinhart, C. M. og Rogoff, K. S. (2008). Is the 2007 U.S. sub-prime crisis so different? An international historical comparison. NBER Working Paper Series, grein 13761. Sótt 12. október 2009 af http://www.nber.org/papers/w13761

Reinhart, C. M. og Rogoff, K. S. (2009). This time is different. Eight centuries of financial folly. Princeton, New Jersey: University Press.

Schwartz, A. J. (2009). Origins of the financial market crisis of 2008. Í P. Booth (ritstjóri), Verdict on the crash: Causes and policy implications (bls. 45-50). London: The Institute of Economic Affairs.

Seðlabanki Íslands. (2006a). The economy of Iceland. Sótt 28. desember 2008 af http://www.sedlabanki.is/lisalib/getfile.aspx?itemid=4689

Seðlabanki Íslands. (2006b). Fitch ratings revises Iceland's outlook to negative. Sótt 28. desember 2008 af http://www.sedlabanki.is/?PageID=287\&NewsID=1124

Seðlabanki Íslands. (2007). The economy of Iceland. Sótt 16. febrúar 2010 af http://sedlabanki.is/lisalib/getfile.aspx?itemid=5387

Seðlabanki Íslands. (2009a). Advantages and disadvantages of changing Iceland's monetary $\begin{array}{llllll}\text { policy } & \text { framework. } & \text { Sótt } & 19 . & \text { ágúst } & 2009\end{array}$ http://www.sedlabanki.is/lisalib/getfile.aspx?itemid=7219 
Seðlabanki Íslands. (2009b). Greiðslujöfnuður við útlönd og erlend staða pjóðarbúsins á öðrum ársfjórðungi 2009. Sótt 11. september 2009 af http://www.sedlabanki.is/?PageID=13\&NewsID=2235

Seðlabanki Íslands. (2010). Bankatöflur. Sótt 15. febrúar 2009 af http://sedlabanki.is/?pageid=444\&itemid=5a037662-26ea-477d-bda8-d71a6017cc05

Shiller, R. J. (2001). Irrational exuberance. New York: Broadway Books.

Thomas, R., Alamutu, T. og Lewis, D. (2006). Icelandic banks. Not what you are thinking. Sótt 6. febrúar 2010 af http://notendur.hi.is/ajonsson/kennsla2006/Merrill\%20Lynch\%20\%20Icelandic\%20Banks.pdf

Valgreen, C. (2006). Iceland: Geyser crisis. Kaupmannahöfn: Danske Bank.

Porvaldur Gylfason. (2009). Bankahrunið: Forsagan og framhaldið. Sótt 5. janúar 2010 af http://hi.is/is/felagsvisindasvid_deildir/hagfraedideild/rannsoknir/malstofur

Pröstur Olaf Sigurjónsson. (2010a). Privatization and Deregulation: A Chronology of Events. Í R. Aliber (ritstjóri.), Documents on the Asset Price bubble in Iceland. Palgrave.

Pröstur Olaf Sigurjónsson. (2010b). The Icelandic Bank collapse: challenges to governance and risk management. Corporate Governance: The International Journal of Business in Society. Emerald Group Publishing. 